\title{
A Synopsis of Neotropical Stylogyne (Myrsinaceae)
}

\author{
Jon M. Ricketson \\ Missouri Botanical Garden, P.O. Box 299, St. Louis, Missouri 63166-0299, U.S.A. \\ jon.ricketson@mobot.org
}

John J. Pipoly III

University of Florida-Institute of Food and Agricultural Sciences/Broward County Extension, Parks and Recreation Division, 3245 College Avenue, Davie, Florida 33314-7719, U.S.A.

jpipoly@broward.org

Aвstract. A complete list of accepted names for the Neotropical genus Stylogyne A. DC. (Myrsinaceae) comprises 35 species and two subspecies. The name Stylogyne lateriflora (Sw.) Mez is neotypified. The following 21 names are lectotypified: Ardisia clusioides Griseb., A. hostmannii Miq., A. surinamensis Miq., Stylogyne amazonica Mez, S. atra Mez, S. balaensis Mez, S. canaliculata (Lodd.) Mez, S. depauperata Mez, S. flumensis (Mez) Ricketson \& Pipoly, S. funckiana Mez, S. kappleri Mez, S. micans Mez, S. nigricans (A. DC.) Mez, S. pauciflora Mez, $S$. poeppigii Mez, S. sellowiana Mez, S. serpentina Mez, $S$. sordida Mez, S. spruceana Mez, S. venezuelana Mez, and S. warmingii Mez. One error in the original protologue is corrected for $S$. darienensis Lundell. Two new combinations, S. fluminensis (Mez) Ricketson \& Pipoly and S. sublaevigata (Kuntze) Ricketson \& Pipoly, are made. Finally, 13 names are newly synonymized within Stylogyne.

Resumen. Se presenta una lista completa de los nombres aceptados para el género Neotropical Stylogyne A. DC., incluyendo a 35 especies y dos subespecies. Se neotipifica el binomio Stylogyne lateriflora (Sw.) Mez y se lectotipifican veintiun bionomios listados a continuación: Ardisia clusioides Griseb., A. hostmannii Miq., A. surinamensis Miq., Stylogyne amazonica Mez, S. atra Mez, S. balaensis Mez, S. canaliculata (Lodd.) Mez, S. depauperata Mez, S. flumensis (Mez) Ricketson \& Pipoly, S. funckiana Mez, S. kappleri Mez, S. micans Mez, S. nigricans (A. DC.) Mez, S. pauciflora Mez, S. poeppigii Mez, $S$. sellowiana Mez, S. serpentina Mez, S. sordida Mez, $S$. spruceana Mez, S. venezuelana Mez y S. warmingii Mez. Se corrige un error dentro del protólogo de $S$. darienensis Lundell. Se propone dos nueva combinaciones, $S$. fluminensis (Mez) Ricketson \& Pipoly y S. sublaevigata (Kuntze) Ricketson \& Pipoly. Además, se relegan 13 bionomios a la sinoníma dentro del género Stylogyne.

Key words: Myrsinaceae, Neotropics, Stylogyne.
The Neotropical genus Stylogyne A. DC. (Myrsinaceae) comprises 35 species, with several others that remain undescribed owing to lack of adequate material. Sexual lability in the genus has been documented (Pipoly, 1989: 1, 1991: 202; Ricketson \& Pipoly, 1997: 591), as well as correlated vegetative variation, which has caused taxonomic overdescription on numerous occasions. Circumscription of the genus Stylogyne has often been problematic due to significant quantitative floral and inflorescence heterogeneity among staminate, pistillate, and bisexual flowers and/or plants. Many species have been described in Ardisia Sw., Geissanthus Hook. f., or Stylogyne and then transferred among the three genera because of confusion in generic boundaries.

Stylogyne is unique among Neotropical genera of Myrsinaceae because of its contorted calyx and corolla lobes, with the corolla lobes variously twisted in bud. Another unique feature of the genus is that inflorescences in Stylogyne are either lateral (axillary) or pseudoterminal, rather than terminal as Mez (1901: 417, 1902: 264) and other authors (Lundell, 1971: 308) had suggested. Based on field observations and detailed examination of specimens, we have discovered that inflorescences formerly considered terminal are, in fact, pseudoterminal, with a small apical bud terminating the branchlet that becomes dormant while the inflorescence develops, subsequently resuming growth after the inflorescence senesces. This phenomenon has been confirmed in the field by Pipoly (pers. obs.) among several species of Stylogyne, such as $S$. turbacensis (Kunth) Mez, S. nigricans (A. DC.) Mez, S. orinocensis (Kunth) Mez, and S. longifolia (Mart.) Mez, while carrying out quantitative forest inventories and population studies. We have also seen this in numerous herbarium specimens, even though the apical bud has at times fallen off, leaving only a discernible apical bud scar. There is one species described by Mez, Stylogyne ambigua, that does have a fully terminal inflorescence, but we follow 
Agostini (1970: 403) in placing it in the genus Geissanthus.

Now that our treatment of the genus Stylogyne has been published for Flora Mesoamericana (Ricketson \& Pipoly, 1997, 2009) and various major floristic checklists are underway (Catálogo de las Plantas Vasculares de Colombia; Listado Florístico de Oaxaca; Catálago Anotado de la Flora del Departamento de Antioquia, Colombia; Catalogue of the Vascular Plants of Bolivia), names in Stylogyne are needed by our colleagues in several countries for their own regional works. Given that it will be some time until a complete systematic monograph can be completed of the genus, we feel it is important to make the names accessible, typified when necessary, with any synonymies based on our current understanding.

Stylogyne A. DC., Ann. Sci. Nat., Bot., Ser. 2, 16: 78, 91. 1841. TYPE: Stylogyne martiana A. DC.

1. Stylogyne aguarunana Pipoly \& Ricketson, Sida 19(2): 269-270, fig. 1. 2000. TYPE: Peru. Amazonas: Bagua Prov., Distr. Imaza, NW region of Río Marañón, Comun. Yamayakat, $04^{\circ} 55^{\prime} \mathrm{S}$, $078^{\circ} 19^{\prime}$ W, 320 m, 5 Aug. 1994 (fl.), N. Jaramillo, A. Peña, R. Apanu \& S. Katip 296 (holotype, MO; isotypes, BRIT, CPUN not seen, F).

2. Stylogyne ardisioides (Kunth) Mez, Pflanzenr. (Engler) IV, 236(Heft 9): 276. 1902. Basionym: Myrsine ardisioides Kunth, Nov. Gen. Sp. (H.B.K.) 3(11): 249. 1819. Ardisia decipiens A. DC., Prodr. 8: 125-126. 1844, nom. superfl. Tinus ardisiodes (Kunth) Kuntze, Revis. Gen. Pl. 2: 973. 1891. TYPE: Peru. "Crescit in Regno Peruviano," s.d. (fl., fr.), A. von Humboldt \& A. Bonpland s.n. (holotype, P-Bonpl., P images as F neg. 38720, IDC no. 76/20/21, MO neg. s.n.).

Ardisia cauliflora Mart. \& Miq., Fl. Bras. (Martius) 10: 291, tab. 35. 1856, syn. nov. Stylogyne cauliflora (Mart. \& Miq.) Mez, Pflanzenr. (Engler) IV, 236(Heft 9): 276. 1902. Tinus cauliflorus (Mart. \& Miq.) Kuntze, Revis. Gen. Pl. 2: 974. 1891. TYPE: Brazil. Amazonas: "Porto dos Miranhas Japurensis, Rio Negro,” Jan. 1820 (fl.), C. Martius s.n. (holotype, M, M image as F neg. 20068).

Icacorea lateriflora Mart., Fl. Bras. 10: 291. 1856, nom. nud., non Ardisia lateriflora Sw., Prodr. (Swartz) 1: 48. 1788.

Stylogyne amplifolia J. F. Macbr., Publ. Field Mus. Nat. Hist., Bot. Ser. 11(1): 33. 1931, syn. nov. TYPE: Peru. Loreto: Caballo-Cocha on Amazon River, Aug. 1929 (fl.), L. Williams 2117 (holotype, F, F image as NY neg. 12131; isotype, US).

Rapanea pallens J. F. Macbr., Candollea 5: 397. 1934, syn. nov. TYPE: Peru. Loreto: Puerto Arturo, lower Río Huallaga, s.d. (fr.), L. Williams 5330 (holotype, F, F image as NY neg. 12257).

Stylogyne gentryi Lundell, Wrightia 5(7): 240. 1976, syn. nov. TYPE: Ecuador. Los Ríos: Hac. Los Ocho, Km 50 on rd. from Santo Domingo to Quevado, 200 m, 4 Feb. 1974 (fl.), A. Gentry 9639 (holotype, LL; isotype, MO).

3. Stylogyne atra Mez, Pflanzenr. (Engler) IV, 236(Heft 9): 273. 1902. TYPE: Brazil. Amazonas: bei Manáos in Waldern, s.d. (fl.), $C$. Schwacke 3671 (lectotype, designated here, GOET; isotype, B[†, 1943], B image as F neg. 4836).

Stylogyne spruceana Mez, Pflanzenr. (Engler) IV, 236(Heft 9): 274. 1902. TYPE: Venezuela. Amazonas: "am Flusse Casiquiare," s.d. (fl.), R. Spruce 3384 (lectotype, designated here, W; isotypes, BM, G-DC, G-DC image as F neg. 26705, K [2], NY, OXF, P, W).

Mez (1902: 273) listed two syntypes for Stylogyne atra "Hylaea: bei Barra am Rio Negro (Spruce n. 1435 et Catal. Monachii conscript. n. 1043), bei Manáos in Wäldren (Schwacke n. 3671, Ill. n. 248)" without mention of herbaria locations. Mez clearly used both collections in his circumscription of the taxon. The Schwacke 3671 collection is in flower; the specimen at $B$ included a detailed drawing of the floral parts, which was unfortunately destroyed in 1943 (Heipko, 1987). However, a sheet of Schwacke 3671 has been located at GOET and is annotated by Mez. Spruce 1435 is a mixed gathering of flowering material collected in April 1851 and fruiting material collected in October 1851. Although the material gathered in fruit of Spruce 1435 is much more widely distributed, we prefer to select flowering material for this taxon. While we have located three flowering collections for Spruce 1435 , only the W sheet was annotated by Mez; however, it is of much poorer quality than the Schwacke 3671 collection at GOET. Therefore, we designate the GOET specimen (Schwacke 3671) as the lectotype.

Mez (1902: 274) listed only the Spruce 3384 collection in the protologue for Stylogyne spruceana, but did not designate a location for the collection. If Mez had a duplicate of this collection at B, it was destroyed in 1943 (Heipko, 1987). A number of duplicates of Spruce 3384 are available (BM, G-DC, K [2], NY, OXF, P, and W). The K [2], NY, OXF, and P sheets are eliminated from the selection of the lectotype because they apparently were not seen by Mez. Although annotated by Mez, the G-DC sheet, which was photographed by Macbride (F neg. 26705), consists of a single leaf blade without a petiole and two inflorescences and is eliminated as fragmentary. The BM and W sheets, both annotated by Mez, are essentially of equal quality, consisting of upper branchlets with a few detached inflorescences. We here select the $\mathrm{W}$ sheet as the lectotype over the BM sheet because it clearly shows the apical bud of the 
branchlet and has more of the stem attached to the base of the inflorescence.

4. Stylogyne bracteolata (Lundell) Pipoly, Ernstia 53: 2. 1989. Basionym: Cybianthus bracteolatus Lundell, Wrightia 6(5): 114. 1980. TYPE: Peru. Amazonas: Condorcanqui Prov., Rio Cenepa Region, al lado de Huampami, monte, 800-850 ft. [244-259 m], 31 July 1974 (fl.), R. Kayap 1409 (holotype, LL; isotype, MO).

5. Stylogyne canaliculata (Lodd., G. Lodd. \& W. Lodd.) Mez, Pflanzenr. (Engler) IV, 236(Heft 9): 268. 1902. Basionym: Ardisia canaliculata Lodd., G. Lodd. \& W. Lodd., Bot. Cab. 11(4): tab. 1083. 1825. Tinus canaliculatus (Lodd., G. Lodd. \& W. Lodd.) Kuntze, Revis. Gen. Pl. 2: 974. 1891. TYPE: Grenada. A cultivated specimen obtained from John Ross and not likely preserved, s.d., J. Ross s.n. (lectotype, designated here, BM, tab. 1083 in Loddiges, 1825).

Ardisia clusioides Griseb., Fl. Brit. W. I. (Grisebach) 4: 396. 1861. TYPE: Dominica. s. loc., s.d. (fl.), J. Imray s.n. (lectotype, designated here, K).

Stylogyne braunii Mez, Symb. Antill. (Urban) 2(3): 417-418. 1901. TYPE. West Indies. Country unknown. Herbarium specimen from cultivated plant in Berlin Botanical Garden (holotype, B[†, 1943]).

Stylogyne smithiorum Mez, Symb. Antill. (Urban) 2(3): 418. 1901. TYPE: Dominica. s. loc., s.d. (fl.), J. Imray s.n. (lectotype, designated by Howard, 1989: 51, K).

Ardisia magdalenae Stehlé, Bull. Soc. Bot. France, Sér. 5, 108(9): 435. 1961. TYPE: France. Martinique: Montague du Vauchin, Sud de l'Île, 502 m, 8 Mar. 1939 (fl., fr.), H. Stehlé 3728 (holotype, P; isotypes, US, W).

Loddiges et al. (1825: 1083) said of the Ross collection for Stylogyne canaliculata, "We received this plant several years since, from our excellent friend John Ross, Esq. of Grenada: it is now grown a handsome shrub." Although we have been unable to locate any original material, the authors do provide a limited description, "a handsone shrub, four or five feet in height; the leaves are nearly four inches in length, oval, and very rich green; the petioles are short, their upper surface remarkabli marginate and channelled; the under part round and smooth. The flowers are produced in terminal panicles, coming out in the winter season," in addition to a color plate, drawn from the original shrub and include the terms "Pentandria" and "Monogynia," as per the classification of the day. We designate the original George Cooke color plate (BM), No. 1083 in volume 11(4) of Conrad Loddiges \& Sons, "The Botanical Cabinet: Consisting of coloured delineations of plants from all Countries, with a short account of each. Directions for management \&c. \&c.," as the lectotype for $S$. canaliculata.

Grisebach (1861: 396) listed four collections in his flora for his new species, Ardisia clusioides: "HAB. Jamaica!, Al. [Alexander Prior], Pd. [Purdie], March [March]; S. Anns, at Moneague, Westmoreland, in the mountains; Dominica, Imr. [Imray]." Although Grisebach worked at the Universität Göttingen (GOET), he relied heavily on the collection at $\mathrm{K}$ for his flora. According to Jochen Heinrichs (pers. comm.), curator of the Herbarium Göttingen, "Some years ago Goettingen scientists extensively checked our [GOET] holdings for Grisebach types, however, the entry regarding Ardisia in $\mathrm{Fl}$ Brit. W. Ind. is completely lacking." However, a single collection of J. Imray s.n. from Dominica is present at $\mathrm{K}$ and is labeled as Ardisia clusioides. We designate this sheet as the lectotype for A. clusioides.

The only material Mez (1901: 418) noted in his original description of Stylogyne braunii was from cultivated material grown "A. Braun temporibus in hort. Berol. culta" at the Berlin Botanical Garden, which noted only this for locality: "Patria ignota, verisimliter Antillae minores et ex affinitate intima speciei sequentis et ex nomie 'Ardisia tinifoliae' adscripto." In his monograph the next year, Mez (1902: 268) noted "Heimat unbekannt, wahrscheinlich Antillen. Früher im bot. Garten Berlin kultiviert (Herb. Berlin)." If any herbarium specimens were made and stored at B, they were unfortunately lost in 1943 (Hiepko, 1987). Although we have not seen any original material of $S$. braunii, the alleged differences noted by Mez (1902: 264) in his key ("Ovarium laeve" vs. "Ovarium valde punctatum") do not logically separate the species in our present understanding of the taxon, as punctation on ovaries varies widely. Based on Mez's (1901: 419, 1902: 268) description, at this time, we choose to refer $S$. braunii to $S$. canaliculata. It is interesting to note that Macbride did not photograph any material associated with this name while at Berlin. We can only speculate as to why this occurred, but perhaps it was due to the fact that no herbarium specimen was present at Berlin before the war. Clearly no material is currently present at B, and no additional material has been found. We suspect that the variation noted by Mez in both of his treatments of this species is due to the fact that the flowers were pistillate instead of staminate or bisexual, as has been observed in the original material of $S$. canaliculata. Thus, due to a lack of material we elect to defer lectotypification at this time.

6. Stylogyne darienensis Lundell, Wrightia 5(3): 68-69. 1974. TYPE: Panama. Darién: slopes of 
Cerro Chucula, drainage of Río Pavarandó, 11 Feb. 1972 (fl.), A. Gentry 4261 (holotype, LL; isotypes, $\mathrm{BM}, \mathrm{MO})$.

Lundell (1974: 69) erred in his original protologue when he cited the collection number as "Al Gentry 4161," which was collected as a Fabaceae. The correct collection number present on all known sheets is 4261 .

7. Stylogyne depauperata Mez, Pflanzenr. (Engler) IV, 236(Heft 9): 277. 1902. Ardisia depauperata (Mez) Bernacci \& Jung-Mend., Acta Bot. Bras. 14(3): 246. 2000. TYPE: Brazil. Rio de Janeiro: Rio de Janeiro, Tijuca, 29 Dec. 1869 (fl.), A. Glaziou 4073 (lectotype, designated here, C; isotypes, B[†, 1943], B image as F neg. 4838, P [2]).

Stylogyne sellowiana Mez, Pflanzenr. (Engler) IV, 236(Heft 9): 278. 1902, syn. nov. TYPE: Brazil. "Brésil," s.d. (fi.), Lalande s.n. (lectotype, designated here, P; isotype, $\mathrm{B}[\dagger, 1943], \mathrm{B}$ image as $\mathrm{F}$ neg. 4838).

Mez (1902: 277) listed five syntypes for Stylogyne depauperata (Beyrich s.n., Glaziou 4073, 6631, 14046, Widgren s.n.) in his original description, but did not note the herbaria. No sheets of the Beyrich s.n. have been located. A single sheet of Widgren s.n. was located at S. Two sheets of Glaziou 4073 as well as a single sheet each of Glaziou 6631 and 14046 are present at $\mathrm{P}$; however, none of the $\mathrm{P}$ material was annotated by Mez. A single sheet of Glaziou 14046 is present at $\mathrm{K}$ and is annotated by Mez. At C, a single sheet of Glaziou 14046 is present (but was not annotated by Mez); a specimen of Glaziou 4073 is also present and was annotated by Mez. The Glaziou 4073 sheet at $\mathrm{C}$ also contains three small drawings (flower bud, stamen, and sepal), presumably by Mez, directly on the sheet. The sheet of the Glaziou 4073 collection at B was annotated by Mez as a "n. sp." and photographed by Macbride (F neg. 4838). The photograph includes a large drawing of the sepals, a petal, and a stamen in ventral and dorsal views; the original sheet and drawing were destroyed in 1943 (Hiepko, 1987). Clearly Mez used the Glaziou 4073 collections at B for his description, but since that sheet was lost, the $\mathrm{C}$ duplicate with the small drawings is designated as the lectotype.

Mez (1902: 278) listed two syntypes for Stylogyne sellowiana, "Rio de Janeiro (Sellow n. 2 [e.p.], Lalande)—Berlin, Paris." The F neg. 4844 is of the Sello $[w] 2 p t$. collection that was destroyed at B in 1943 (Hiepko, 1987). No other Sellow n. 2 [e.p.] material has been located either at B or P. The Lalande s.n. syntype at $\mathrm{P}$ is annotated by $\mathrm{Mez}$ and, since all B material was destroyed, the $\mathrm{P}$ sheet is designated as the lectotype.

8. Stylogyne dusenii Ricketson \& Pipoly, Novon 19(4): 497, fig. 1. 2009. TYPE: Brazil. Paraná: Volta Grande, 19 Nov. 1911 (fl.), P. Dusén s.n. (holotype, $\mathrm{GH}$; isotype, $\mathrm{S}$ not seen).

9. Stylogyne fluminensis (Mez) Ricketson \& Pipoly, comb. nov. Basionym: Ardisia fluminensis Mez, Pflanzenr. (Engler) IV, 236(Heft 9): 95-96. 1902. Icacorea fluminensis (Mez) Lundell, Phytologia 49(4): 348. 1981. TYPE: Brazil. Rio de Janeiro: Montoris Rio de Janerio, s.d. (fl.), $P$. Lund s.n. (lectotype, designated here, C; isotype, LL [fragm.]).

Stylogyne warmingii Mez, Pflanzenr. (Engler) IV, 236(Heft 9): 278. 1902, syn. nov. Ardisia warmingii (Mez) Bernacci \& Jung-Mend., Acta Bot. Bras. 14(3): 246. 2000. TYPE: Brazil. São Paulo: Lagoa Santa, 23 Dec. 1863 (fl.), J. Warming 522 (lectotype, designated here, C, C image as F neg. 22971).

Mez (1902: 96) listed three syntypes for Ardisia fluminensis: "Ost-Brasilien: Staat Rio de Janeiro in der Serra dos Orgãos, bei Mandiocca (Lund, Mikan, Sellow n. 207).-(Herb. Berlin, Wien, Warming [C])." We have been unable to locate any material collected by Mikan associated with this taxon. The B sheet of the Sellow 207 collection had a detailed drawing of the floral parts and was photographed by Macbride (F neg. 4878), but the sheet was destroyed in 1943 (Hiepko, 1987). A sheet of P. Lund s.n. is present at $\mathrm{C}$ [Hb. Warming], and we designate it as the lectotype.

Mez (1902: 278) listed three syntypes for Stylogyne warmingii: "Süd-Brasilien: Prov. São Paulo bei Lagoa Santa, San José de Río Pardo, Esp. Santo do Pinchal (Löfgren 1434, 3304, Warming 522).-Blüht November, Dezember.-Herb. Comm. geogr. geol. São Paulo, Warming." No material of Löfgren 1434 or 3304 has been located. Imkhanitskaya (1996a: 29) previously lectoypified this taxon, but erroneously from the material present at LE. He states that the Warming collections arrived at LE unnumbered, and he specifically designates the unnumbered collection at $\mathrm{C}$ as the lectotype. However, Mez clearly states in his protologue that he used the $J$. Warming 522 collection at $\mathrm{C}$ for his taxon. This sheet is still present at $\mathrm{C}$ and is annotated by Mez. We designate the J. Warming 522 collection at $\mathrm{C}$ sheet as more consistent with the describing author's original intent.

10. Stylogyne glomeruliflora Cuatrec., Revista Acad. Colomb. Ci. Exact. 8(31): 326. 1951. 
TYPE: Colombia. Valle del Cauca: Cordillera Occidental, vertiente occidental, hoya del río Dígua, Río San Juan, abajo de Queremal a la derecha del río entre Km 52 y 53, 1300-1500 m, 19 Mar. 1947 (fl.), J. Cuatrecasas 23847 (holotype, F; isotypes, COL, US).

11. Stylogyne hayesii Mez, Pflanzenr. (Engler) IV, 236(Heft 9): 272. 1902. TYPE: Panama. Darién: Manené [Manmer Station], Panama Railroad, 15 Oct. 1862 (fl.), S. Hayes 662 (holotype, G-BOIS; isotypes, BM, K, P).

12. Stylogyne incognita Pipoly, Brittonia 51(2): 130, fig. 2. 1999. TYPE: French Guiana. Pied du Mont Galbao, crique Canal Panama, $03^{\circ} 37^{\prime} \mathrm{N}$, $053^{\circ} 16^{\prime} \mathrm{W}$, ca. $200 \mathrm{~m}, 7$ Jan. 1986 (fl.), J. de Granville, C. Feuillet, L. Hollenberg, O. Poncy \& M. Sangrey 8401 (holotype, CAY; isotypes, B, MG not seen, MO, NY, P, U, US [2]).

13. Stylogyne indecora Mez, Pflanzenr. (Engler) IV, 236(Heft 9): 277. 1902. Ardisia cauliflora Mart. \& Miq. var. parvifolia Miq., Fl. Bras. (Martius) 10: 291. 1856. TYPE: Brazil. Pará: “in silvis prope urbem Pará, locis editioribus, s.d. (fl.), C. Martius s.n. (holotype, M, M image as F neg. 20069).

14. Stylogyne lasseri (Lundell) Pipoly, Ernstia 53: 4, fig. 1. 1989. Basionym: Ardisia lasseri Lundell, Wrightia 4(2): 59. 1968. Icacorea lasseri (Lundell) Lundell, Phytologia 49(4): 349. 1981. TYPE: Venezuela. Bolívar: selvas alrededor de Santa Elena, 1946 (fr.), T. Lasser 1570 (holotype, VEN, VEN image as NY neg. 12106, LL neg. 1971-58A; isotypes, LL [fragm.], NY, US, VEN, VEN image as LL neg. 1971-58B).

15. Stylogyne lateriflora (Sw.) Mez, Symb. Antill. (Urban) 2(3): 418. 1901. Basionym: Ardisia lateriflora Sw., Prodr. (Swartz) 1: 48. 1788. Anguillaria lateriflora (Sw.) Lam., Tabl. Encycl. 4 (2): 109. 1797. Anguillaria lateriflora (Sw.) Poir., Encycl. 7: 687. 1806, nom. superfl. Badula lateriflora (Sw.) Griseb., Abh. Königl. Ges. Wiss. Göttingen 7: 237. 1857. Tinus lateriflorus (Sw.) Kuntze, Revis. Gen. Pl. 2: 974. 1891. TYPE: Guadeloupe. Basse Terre: Bois des Basse-Terre, 490-950 m, 1892-1894 (fl.), P. Duss 2283 (neotype, designated here, NY; isotypes, F, GH, NY [2], PH, US [2]).

Badula caribaea A. DC., Ann. Sci. Nat., Bot., Sér. 2, 16: 90. 1841. Ardisia caribaea (A. DC.) Miq., Fl. Bras. (Martius) 10: 289. 1856. Tinus caribaeus (A. DC.) Kuntze, Revis. Gen. Pl. 2: 974. 1891. TYPE: St. Vincent and the Grenadines. St. Vincent: s. loc., 1828 (fl.), L. Guilding 14 (holotype, G-DC, G-DC images as IDC 1442/14, F neg. 33855, MO neg. s.n.).

Stylogyne tenuifolia Britton, Bull. Torrey Bot. Club 50(1): 53. 1923. TYPE: Trinidad and Tobago. Trinidad: Mt. Tocuche, 3-5 Apr. 1920 (fr.), N. Britton, T. Hazen \& W. Mendleson 1341 (holotype, GH; isotypes, NY, US).

The travels and history of the publication of Swartz's Prodromus (1788) were well documented by Stearn (1980), Howard and Howard (1982), and Nicolson and Jarvis (1990). Swartz (1788: 48) described five new Ardisia from the Caribbean. It has long been assumed that most of Swartz's new species were based on his own collections. However, Nicolson and Jarvis (1990: 622) paraphrase a statement made by Swartz as: "[m]y Prodromus is made up from my own collections and those in the Banksian herbarium. The new things that Solander identified and I had not collected are marked with an asterisk." A closer look at the entry by Swartz (1788: 48) for the new species Ardisia lateriflora reveals an asterisk (*) following the description, indicating that the concept of this species came from Solander's unpublished manuscript "Florula Indiae Occidentalis" and not from material collected by Swartz. In addition, Swartz cites the type locality simply as "India occidentalis" with no indication of collector. Nicolson and Jarvis (1990: 620) were able to translate most of Solander's manuscript and deciphered many of the cryptic notes. However, for the entry of this species, no detailed locality or collector information was discovered. Until now, most authors have accepted the idea that this species was based on an unnumbered Swartz collection housed at BM. Howard and Howard (1982) tried to lectotypify many of the names associated with the species in Swartz's Prodromus but were unable to resolve the type ambiguity for A. lateriflora Sw. Howard (1989: 52) indicated his uncertainty regarding this material when he stated, "Type: 'India occidentalis.' No specimens cited, but type should be in the Herb. Banks (BM)." At this time, no material that could be used as the type for the basionym, Ardisia lateriflora Sw., has been located either at BM or S (including the Swartz herbarium). We designate a collection of Père Duss 2283 at NY as the neotype, because we think it best represents this taxon in the West Indies and it has numerous isotypes available. Finally, we here exclude two synonyms classically associated with this species (Mez, 1901: 419, 1902: 275), Ardisia acuminata Spreng. [= Ardisia guyanensis (Aubl.) Mez in Urb.] and Anguillaria laurifolia Lam. $[=$ Wallenia lamarckiana (A. DC.) Mez in Urb.].

16. Stylogyne laxiflora Mez, Pflanzenr. (Engler) IV, 236(Heft 9): 273. 1902. Badula laxiflora 
Benth., in sched., in Mez, 1902: 273, nom. nud. Replacement synonym: Ardisia spruceana Carrijo, M. F. Freitas \& Pexoto, Nordic J. Bot. 27: 454-455. 2009, non Ardisia laxiflora Merr., Philipp. J. Sci. 12: 153. 1917. TYPE: Brazil. "San Gabriel de Cachoeira am Rio Negro," s.d. (fl.), R. Spruce 2173 (lectotype, designated by Carrijo et al., 2009: 454, NY [barcode 00329330]; isotypes, $\mathrm{B}[\dagger, 1943], \mathrm{B}$ image as $\mathrm{F}$ neg. 4839, BM, C, E, G, G-BOIS, G-DC, GOET, $\mathrm{K}$ [3], OXF, P [2], W [2]).

Mez (1902: 273) listed only the Spruce 2173 collection for this taxon; however, he did not indicate at what institution he saw it. A number of sheets of the collection are present from numerous herbaria as noted above and most were annotated by Mez. According to Mez (1902: 273), the epithet is based on "Badula laxiflora Benth.! in plant. exsicc. Spruce 2173" apparently from an unpublished list or annotation, presumably by Bentham at K. The B holotype had an attached detailed drawing of the flower and was photographed by Macbride (F neg. 4839); however, that sheet was destroyed in 1943 (Hiepko, 1987). Carrijo et al. (2009: 454) lectotypified the name from the NY sheet, but there is no evidence that this sheet was seen by Mez. While we assert that the NY sheet is a poor choice, we must accept it as the lectotype according to the International Code of Botanical Nomenclature (McNeill et al., 2006: Art. 43). Carrijo et al. (2009: 454) misinterpreted statements of Pipoly and Ricketson (2005: 190) that most Neotropical Ardisia have filaments fused only basally, but free from the corolla. Fused filaments are not unique to Ardisia, but are rather common. What is unusual is that the filaments are fused to each other at the very base, but the entire androecium is free and not adnate to the corolla. In addition, the corolla lobes of Stylogyne laxiflora are contorted, clearly distinguishing the taxon from Ardisia.

17. Stylogyne leptantha (Miq.) Mez, Pflanzenr. (Engler) IV, 236(Heft 9): 267. 1902. Basionym: Ardisia leptantha Miq., Fl. Bras. (Martius) 10: 286-287, tab. 32. 1856. Tinus leptanthus (Miq.) Kuntze, Revis. Gen. Pl. 2: 974. 1891. TYPE: Brazil. Minas Gerais: central Brazil, s.d. (fl.), J. Pohl s.n. (holotype, M).

18. Stylogyne lhotskyana (A. DC.) Mez, Pflanzenr. (Engler) IV, 236(Heft 9): 269. 1902, as "lhotzkyana." Basionym: Ardisia lhotskyana A. DC., Trans. Linn. Soc. London 17(1): 127. 1834, as "lhotskya." Badula lhotskyana (A. DC.) A. DC., Prodr. (DC.) 8: 111. 1844. Tinus lhotzkyanus (A.
DC.) Kuntze, Revis. Gen. Pl. 2: 974. 1891, as "lhotskya." TYPE: Brazil. ca. Rio [de] Janeiro, 1832 (fl.), J. Lhotsky s.n. (holotype, G-DC, G-DC images as F neg. 7479, MO neg. s.n.).

19. Stylogyne longifolia (Mart.) Mez, Pflanzenr. (Engler) IV, 236(Heft 9): 276. 1902. Basionym: Ardisia longifolia Mart., Fl. Bras. (Martius) 10: 290. 1856. Tinus longifolius (Mart.) Kuntze, Revis. Gen. Pl. 2: 974. 1891. TYPE: Brazil. Amazonas: "crescit in silvis horrendis ditionis Japurensis," Jan. 1820 (fl.), C. Martius s.n. (holotype, M, M image as F neg. 20071).

20. Stylogyne martiana A. DC., Ann. Sci. Nat., Bot., Sér. 2, 16: 91. [Aug.] 1841. Ardisia latipes Mart., Herb. Fl. Bras. 570. 1841, nom. nud. Ardisia latipes Mart., Flora 24 (Beibl. 2): 62. [Sep.] 1841. Tinus martianus (A. DC.) Kuntze, Revis. Gen. Pl. 2: 974. 1891. Stylogyne latipes (Mart.) Imkhan., Bot. Žhurn. (Moscow \& Leningrad) 81(9): 32. 1996. TYPE: Brazil. "Ilheos in sylvis umbrosissimis," 1839 (fl.), C. Martius 570 (holotype, G-DC, G images as F neg. 7477, MO neg. s.n.; isotypes, BM, G [Hb. Moricand], G-BOIS, GH, K, LE, M [2], NY, OXF, P, W [2]).

Much confusion has surrounded the type associated with the $C$. Martius 570 collection, even as late as 1996 (Imkhanitskaya, 1996b: 32). According to Farr et al. (1979: 1700), in Index Nominum Genericorum, the publication date of Alphonse de Candolle's article in Ann. Sci. Nat., Bot., Sér. 2 (1841), which also described the genus Stylogyne, was August 1841. According to Stafleu and Cowan (1981: 333), Martius' (1841) article in Flora 24(Beibl. 2) was published on 21 September 1841. We believe this clearly gives priority to Alphonse de Candolle's taxa and $S$. martiana over the Martius name.

21. Stylogyne mathewsii Mez, Pflanzenr. (Engler) IV, 236(Heft 9): 278. 1902. TYPE: Peru. Pangoa, s.d. (fl.), M. Mathews 1200 (holotype, K [Hb. Benth.]; isotypes, E [2], $\mathrm{K}$ [Hb. Hook.], OXF).

Mez (1902: 278) listed only Mathews 1200 from K for this taxon. However, there are two sheets of the collection at $\mathrm{K}$, one in the Bentham herbarium and annotated by Mez as "Ardisia ? mathewsii n. sp." and the other in the Hooker herbarium, but not annotated by Mez. We assume then that Mez based this taxon on the Bentham herbarium sheet and not the Hooker herbarium sheet, and thus there is no need for lectotypification. 
22. Stylogyne membranacea Pipoly, Ernstia 53: 6, fig. 2. 1989. TYPE: Venezuela. Táchira: Cerro Las Minas, $18 \mathrm{~km}$ SE of Santa Ana, pasture with forest along steep slopes leading to Cerro Azul of Cerro Las Minas, $07^{\circ} 36^{\prime} \mathrm{N}, 072^{\circ} 13^{\prime} \mathrm{W}, 1200-$ 1380 m, 6 May 1981 (fl., fr.), R. Liesner \& M. Guariglia 11876 (holotype, VEN, VEN image as NY neg. 12105; isotypes, LL, MO, US).

23. Stylogyne micrantha (Kunth) Mez, Pflanzenr. (Engler) IV, 236(Heft 9): 276. 1902. Basionym: Ardisia micrantha Kunth, Nov. Gen. Sp. (H.B.K.) 3(11): 246. 1819. Bumelia micrantha (Kunth) Willd. ex Roem. \& Schult., Syst. Veg., ed. 15 bis (Roemer \& Schultes) 4: 802. 1819. Tinus micranthus (Kunth) Kuntze, Revis. Gen. Pl. 2: 974. 1891. TYPE: Colombia. "Crescit in ripa fluminis Magdalenae, prope Tenerife," Apr. (fl.), A. von Humboldt \& A. Bonpland 1471 (holotype, P-Bonpl., P image as MO neg. s.n.; isotypes, B-W [4606], B image as F neg. 4841, P).

Stylogyne venezuelana Mez, Pflanzenr. (Engler) IV, 236(Heft 9): 273-274, fig. 45. 1902. TYPE: Venezuela. "Prope Coloniam Tovar," 1856-1857 (fl.), A. Fendler 2355 (lectotype, designated here, K).

Stylogyne latifolia A. C. Sm., Lloydia 2(3): 203. 1939. TYPE: British Guiana [Guyana]. Basin of Essequibo River, near mouth of Onoro Creek, along river, $01^{\circ} 35^{\prime} \mathrm{N}, 15-$ 24 Dec. 1937 (fr.), A. C. Smith 2808 (holotype, NY; isotypes, MO, S, U, US).

Mez (1902: 274) listed two collections for the type of Stylogyne venezuelana, "Venezuela: bel Puerto-Cabellos (Karsten. n. 176), bei Tovar (Fendler n. 2355).Herb. Berlin, Boiss.-Barbey, DC., A. Gray, Wien." The syntypic material for this name is questionable. Obviously any of the material Mez used at B was destroyed in 1943 (Heipko, 1987). This possibly includes the material used for the illustration in the protologue (Mez, 1902: 274, fig. 45). At W is a sheet annotated by Mez as "Stylogyne venezuelana n. sp.," from "Colonia Tovar," but without further determination to collector name or number, although the date and location are not inconsistent with a Fendler collection. At G, also annotated by Mez as "Stylogyne venezuelana n. sp.," are two Karsten collections (G-BOIS and GDC), but both sheets are numbered as " $a$ " and not " 176 " as in the original protologue. A search of the collections at $\mathrm{GH}$ has failed to reveal either syntype. There is a specimen of the Fendler 2355 collection at $\mathrm{K}$, unfortunately not annotated by Mez. However, given the ambiguity of the $\mathrm{G}$ and $\mathrm{W}$ material we designate the $\mathrm{K}$ material as the lectotype.

24. Stylogyne minutiflora Cuatrec., Revista Acad. Colomb. Ci. Exact. 8(31): 326. 1951. TYPE:
Colombia. Boyacá: Region of Mt. Chapón, NW of Bogotá, extreme W part of Dept. Boyaca, $3600 \mathrm{ft}$. [1097 m], 22 May 1932 (fl.), A. Lawrance 86 (holotype, F, F image as NY neg. 12124; isotypes, A, COL, LL, NY, UC, US).

25. Stylogyne nigricans (A. DC.) Mez, Pflanzenr. (Engler) IV, 236(Heft 9): 267. 1902. Basionym: Badula nigricans A. DC., Ann. Sci. Nat., Bot., Sér. 2, 16: 90-91. 1841. Ardisia nigricans (A. DC.) Miq., Fl. Bras. (Martius) 10: 289-290. 1856. Tinus nigricans (A. DC.) Kuntze, Revis. Gen. Pl. 2: 974. 1891. TYPE: Brazil. "Fluvium Nigrum" [Rio Negro], s.d. (fl.), s. coll. (lectotype, designated here, P).

Ardisia panurensis Mez, Pflanzenr. (Engler) IV, 236(Heft 9): 95. 1902, syn. nov. Icacorea panurensis (Mez) Lundell, Phytologia 49(4): 350. 1981. TYPE: Brazil [as Pará]. Amazonas: "prope Panurè ad Río Uaupès," Oct. 1852Jan. 1853 (fl.), R. Spruce 2542 (holotype, G-DC, G image as F neg. 26667; isotypes, B[†, 1943], BM, GBOIS, K, OXF, P).

Stylogyne brunnescens Mez, Pflanzenr. (Engler) IV, 236(Heft 9): 267. 1902, syn. nov. TYPE: Brazil. Amazonas: Panurè am Río Uaupès," s.d. (fl.), R. Spruce 2665 (holotype, G [Hb. Deless.], G image as F neg. 26702; isotypes, $\mathrm{GH}, \mathrm{K}, \mathrm{P}$ ).

In Alphonse de Candolle's (1841: 91) description of Badula nigricans, he listed two collections "Hab. circa Para et ad fluvium Nigrum (Rio Negro)" both in "(V. in h. Mus. Par.)," both collections are still present at P. The Pará collection, if ever fertile, is now sterile. Thus we designate the Rio Negro collection, which is flowering, as the lectotype.

26. Stylogyne orinocensis (Kunth) Mez, Pflanzenr. (Engler) IV, 236(Heft 9): 270. 1902. Basionym: Ardisia orinocensis Kunth, Nov. Gen. Sp. [H.B.K.] 3(12): 244. 1819. Tinus orinocensis (Kunth) Kuntze, Revis. Gen. Pl. 2: 974. 1891. TYPE: Venezuela. "Crescit ad ripam Orinoci, inter cataractas Aturensium et pagum San Borja," May (fl.), A. von Humboldt \& A. Bonpland 842 (holotype, P-Bonpl., P image as MO neg. s.n.; isotypes, $\mathrm{B}[\dagger, 1943], \mathrm{B}$ image as $\mathrm{F}$ neg. 4842, B-W [2]).

Badula schomburgkiana A. DC., Ann. Sci. Nat., Bot., Sér. 2, 16: 90 . 1841, syn. nov. Ardisia schomburgkiana (A. DC.) Miq., Fl. Bras. (Martius) 10: 289. 1856. Tinus schomburgkianus (A. DC.) Kuntze, Revis. Gen. Pl. 2: 975. 1891. Stylogyne schomburgkiana (A. DC.) Mez, Pflanzenr. (Engler) IV, 236(Heft 9): 270. 1902. TYPE: Guyana. s. loc., 1837 (fl.), R. Schomburgk 306 (holotype, G-DC; isotypes, BM, G-BOIS, G [Hb. Deless.], K, U, US, W).

Badula schomburgkiana A. DC. var. brasiliensis A. DC., Prodr. (DC.) 8: 111. 1844, syn. nov. Stylogyne 
brasiliensis (A. DC.) Mez, Pflanzenr. (Engler) IV, 236(Heft 9): 269. 1902. TYPE: Brazil. s. loc., s.d. (fl.), s. coll. s.n. (holotype, P).

Ardisia surinamensis Miq., Fl. Bras. (Martius) 10: 288. 1856. Stylogyne surinamensis (Miq.) Mez, Pflanzenr. (Engler) IV, 236(Heft 9): 271. 1902. Tinus surinamensis (Miq.) Kuntze, Revis. Gen. Pl. 2: 975. 1891. TYPE: Suriname. "Crescit in Suriname...In Brasilia amazonica detegenda," 1843 (fl.), F. Hostmann 617 (lectotype, designated here, G [Hb. Deless.], G image as F neg. 26706; isotypes, BM, C, G-BOIS, K [2], P, W [4]).

Ardisia hostmannii Miq., Fl. Bras. (Martius) 10: 288. 1856, as "hostmanni." Tinus hostmannii (Miq.) Kuntze, Revis. Gen. Pl. 2: 974. 1891. TYPE: Suriname. "Crescit in Suriname," 1840-1843 (fl.), F. Hostmann 166 (lectotype, designated here, K [Benth.]; isotypes, BM [2], G [Hb. Deless.], G-BOIS, K [Hb. Hook.], P, W [3]).

Stylogyne micans Mez, Pflanzenr. (Engler) IV, 236(Heft 9): 272-273. 1902. TYPE: Suriname. "Am Lava-Fluss," s.d. (fl.), A. Kappler \& F. Hostermann 2106 (lectotype, designated here, W; isotypes, G-DC, GOET, P, W).

Stylogyne poeppigii Mez, Pflanzenr. (Engler) IV, 236(Heft 9): 274-275. 1902, syn. nov. TYPE: Brazil. Amazonas: Ega [Teffé], Dec. 1831 (fl.), E. Poeppig 2887 (lectotype, designated here, W, W image as F neg. 31983; isotypes, B[†, 1943], W [2]).

Stylogyne amazonica Mez, Pflanzenr. (Engler) IV, 236(Heft 9): 275. 1902. TYPE: Brazil. Amazonas: "San Gabriel da Cachoeira am Rio Negro," s.d. (fl.), R. Spruce 2200 (lectotype, designated here, $\mathrm{K}$; isotypes, BM, C, C image as F neg. 22980, E, G-BOIS, G-DC, G [Hb. Deless.], G image as MO neg. s.n., GH, GOET, K [2], NY, P [2], W [2]).

Stylogyne kappleri Mez, Pflanzenr. (Engler) IV, 236(Heft 9): 275. 1902. TYPE: Dutch Guyana [Suriname]. Paramaribo: Mar.-Apr. (fl.), A. Kappler 1633 (lectotype, designated here, G-BOIS; isotypes, G [Hb. Deless.], G image as F neg. 26703, GOET, MO, P [4], W).

Martius and Miquel (1856: 288) published the names Ardisia surinamensis and A. hostmannii, with reference only to the country. For the type of $A$. surinamensis, we designate the $G$ sheet in the Delessert collection as the lectotype, because it is associated with a Macbride type photograph at $\mathrm{F}$, which was widely distributed and is readily available.

The Hostmann collections were widely distributed, and all the material is more or less of equal value. For the type of Ardisia hostmannii, we designate the material at $\mathrm{K}$ from the Bentham herbarium as the lectotype, because it is the best sheet of the gathering.

Mez (1902: 273) listed two different collections and three different herbaria for the type of Stylogyne micans: "Holländisch-Guyana: am Lava-Fluss; Französisch-Guyana: ohne Standortsanfabe (Kappler n. 2106, Moricand n. 10)—Blüht im October. (Herb. DC., Goetting., Wien.)." All the material of Moricand 10 we have observed (G [2], NY) is of poor quality, with small inflorescences and poorly pressed leaves. The Kappler 2106 collections from G-DC, GOET, P, and $\mathrm{W}$ are of much better quality. The specimen at $\mathrm{W}$ is of fine quality and we designate it as lectotype.
Mez (1902: 275) listed only the Poeppig 2887 collections from B and W for his Stylogyne poeppigii. The B material was destroyed in 1943 (Heipko, 1987). However, three sheets of this collection are present at $\mathrm{W}$, two of which were annotated by Mez. We designate the annotated sheet photographed by Macbride (F neg. 31983), without accession number by $W$, as the lectotype.

Mez (1902: 275) listed only the $R$. Spruce 2200 collection for the type of Stylogyne amazonica, but failed to indicate any herbarium of deposit. Although the type material was widely distributed, the most significant Spruce collections are at $\mathrm{K}$ and therefore we designate the $\mathrm{K}$ sheet as the lectotype.

Mez (1902: 275) listed only the A. Kappler 1633 collections for the type of Stylogyne kappleri from "Herb. Boiss.-Barbey, Deless., Wien." All this material is available, but the G-BOIS sheet is by far the better sheet and we designate it as the lectotype.

27. Stylogyne pauciflora Mez, Pflanzenr. (Engler) IV, 236(Heft 9): 278-279. 1902. TYPE: Brazil. São Paulo: s. loc., s.d. (fl.), H. Sello $[w] 472$ (lectotype, designated here, B, B image as B neg. 96121; isotypes, B, B image as B neg. 96120 , $\mathrm{B}[\dagger, 1943], \mathrm{B}$ image as $\mathrm{F}$ neg. 4843).

Ardisia handroi Toledo, Loefgrenia 39: 2. 1969, syn. nov. TYPE: Brazil. São Paulo: São Paulo, "nativa no Parque do Estado e Jardim Botânico," 30 Oct. 1935 (fl.), O. Handro s.n. (holotype, SP not seen; isotypes, HB not seen, NY, SI not seen, US).

Mez (1902: 279) listed two syntypes for Stylogyne pauciflora, from "Süd-Brasilien: Säo Paulo ohne Standorsangabe (Gaudichaud s.n., Sellow 472)—Herb. Berlin, Paris." A sheet of C. Gaudichaud from São Paulo is present at $\mathrm{P}$, with an annotation by Mez. However, it is labeled as "Herbier Impérial Brésil 36," and it remains unclear if this is the material Mez cited in his protologue. Because of the confusion of this material, it is eliminated as a possible lectotype. Macbride photographed a specimen of Sellow 472 at B (F neg. 4843), which was annotated by Mez and had a large drawing of the floral parts; however, that sheet was destroyed in 1943 (Hiepko, 1987). Fortunately, two sheets annotated by Mez of Sellow 472 are still held at B, and both of these sheets match the destroyed B material; unfortunately, neither has any additional locality data. The B sheet, as imaged by $\mathrm{B}$ neg. 96121 , is by far the best sheet and is designated as the lectotype.

28. Stylogyne pucuroensis Ricketson \& Pipoly, Sida 20(3): 919, fig. 1. 2003. TYPE: Panama. 
Darién: Parque Nac. del Darién, ridge betw. N \& $\mathrm{S}$ branches of Río Pucuro, in forest $\mathrm{N}$ of old village of Tacarcuna, ca. $18 \mathrm{~km} \mathrm{E}$ of Pucuro, $08^{\circ} 05^{\prime} \mathrm{N}, 077^{\circ} 16^{\prime} \mathrm{W}, 600-800 \mathrm{~m}, 24$ Oct. 1987 (fr.), B. Hammel, G. de Nevers, H. Cuadros V. \& H. Herrera 16469 (holotype, MO; isotypes, BRIT, LL, PMA).

29. Stylogyne racemiflora Ricketson \& Pipoly, Novon 19(4): 499, fig. 2. 2009. TYPE: Brazil. Amazonas: Mpio. São Gabriel da Cachoeira, Morro dos Seis Lagos, Lago do Dragão, 400450 m, 14-15 Oct. 1987 (fl.), C. Farney, D. Daly, D. Stevenson, J. Oliveira \& R. de Lima 1705 (holotype, MO; isotypes, GH, INPA not seen, K, MO, NY, US).

30. Stylogyne rodriguesiana Pipoly, Novon 1(4): 202, fig. 1. 1991. TYPE: Brazil. Amazonas: Manaus, Igarapé do Cachoira, Alta de Taruma, 4 Aug. 1961 (fl.), W. Rodríguez \& F. Chagas 3092 (holotype, INPA; isotype, NY).

31. Stylogyne serpentina Mez, Repert. Spec. Nov. Regni Veg. 16(468-473): 420-421. 1920. TYPE: Brazil. Acre: Rio Acre, Seringal Auristella, May 1911 (fl.), E. Ule 9688 (lectotype, designated here, $\mathrm{K}$; isotypes, $\mathrm{B}[\dagger$, 1943], B image as $\mathrm{F}$ neg. 4845, L, NY).

Rapanea chartacea J. F. Macbr., Candollea 5: 396. 1934, syn. nov. Stylogyne chartacea (J. F. Macbr.) J. F. Macbr., Publ. Field Mus. Nat. Hist., Bot. Ser. 13(5/1): 194. 1959. TYPE: Peru. Loreto: Maynas Prov., Iquitos, 120 m, Mar.-Apr. 1930 (fl. bud), L. Williams 8049 (holotype, F, F image as NY neg. 12126; isotype, US).

Mez (1920: 421) listed only the Ule 9688 collection in the protologue without specifying a location. The sheet of Ule 9688 housed at Berlin was photographed by Macbride (F neg. 4845) and clearly shows Mez's annotation, but this was destroyed in 1943 (Hiepko, 1987). Among the remaining isotypes at L, K, and NY, none were annotated by Mez; however, they all correspond to the $\mathrm{F}$ image of the $\mathrm{B}$ specimen. We designate the $\mathrm{K}$ sheet as the lectotype, because it is a higher quality specimen with critical vegetative and floral parts more evident than seen on the other sheets.

32. Stylogyne sordida Mez, Pflanzenr. (Engler) IV, 236(Heft 9): 277. 1902. TYPE: Brazil. Prov. de Rio de Janeiro, voyage d'Auguste, 1816-1821 (fl.), Saint Hilaire $A^{I} 560$ (lectotype, designated here, $\mathrm{P}$; isotypes, $\mathrm{B}[\dagger$, 1943], B image as $\mathrm{F}$ neg. $4846, \mathrm{P})$.

Mez (1902: 277) listed two syntypes for Stylogyne sordida, from Rio de Janeiro "(Saint-Hilaire A ${ }^{1}$ n. 560 and Sellow n. 2 [e.p.])—Herb. Berlin, Paris." The B sheet of the Sello $[w] 2$ collection annotated by Mez had a detailed drawing of the floral parts and was photographed by Macbride (F neg. 4846), but the sheet was destroyed in 1943 (Hiepko, 1987). At this time no other material of the Sello $[w]$ collection has been located. If a sheet of Saint-Hilaire $A^{l} n .560$ was ever present at B, it also was lost in 1943. However, two sheets of the Saint-Hilaire $A^{l} n .560$ collection are at $\mathrm{P}$; one was not annotated by Mez and is a much poorer specimen. The other $\mathrm{P}$ collection of SaintHilaire $A^{l} n .560$ is of higher quality and is annotated by Mez; we designated it as the lectotype.

33. Stylogyne sublaevigata (Kuntze) Ricketson \& Pipoly, comb. nov. Basionym: Ardisia martiana Miq., Fl. Bras. (Martius) 10: 285, tab. 30. 1856. Icacorea laevigata Mart. \& Miq., Fl. Bras. (Martius) 10: 285. 1856, nom. nud. Replacement synonym: Tinus sublaevigatus Kuntze, Revis. Gen. Pl. 2: 974. 1891, non Stylogyne martiana A. DC., Ann. Sci. Nat., Bot., Sér. 2, 16: 91. 1841. Stylogyne laevigata Mez, Pflanzenr. (Engler) IV, 236(Heft 9): 266-267. 1902, nom. illeg. TYPE: Brazil. "Crescit in nemoribus perpetuis prov. Sebastianopolitanae prope praedium Mandioccam, Río de Janiero," Sep. (fl.), C. Martius s.n. (holotype, M, M image as F neg. 20070).

34. Stylogyne turbacensis (Kunth) Mez, Pflanzenr. (Engler) IV, 236(Heft 9): 270. 1902. Basionym: Ardisia turbacensis Kunth, Nov. Gen. Sp. (H.B.K.) 3(12): 245-246. 1819. Tinus turbacensis (Kunth) Kuntze, Revis. Gen. Pl. 2: 975. 1891. TYPE: Colombia. Antioquia: Turbo Mpio., near Turbaco [Turbo], s.d. (fr.), A. von Humboldt \& A. Bonpland 1446 (holotype, P-Bonpl.; isotype, $\mathrm{P})$.

34a. Stylogyne turbacensis subsp. laevis (Oerst.) Ricketson \& Pipoly, Sida 17(3): 595. 1997. Basionym: Ardisia laevis Oerst., Vidensk. Meddel. Naturhist. Foren. Kjøbenhavn, Ser. 2, 1861(8-9): 125. 1862. Tinus laevis (Oerst.) Kuntze, Revis. Gen. Pl. 2: 974. 1891. Stylogyne laevis (Oerst.) Mez, Pflanzenr. (Engler) IV, 236(Heft 9): 268. 1902. TYPE: Costa Rica. Cartago: Monte Irasu [Irazú], Jan. 1847 (fl.), A. Oersted 28 (lectotype, designated by Lundell, 1966: 199, C).

Ardisia ramiflora Oerst., Vidensk. Meddel. Naturhist. Foren. Kjøbenhavn, Ser. 2, 1861(8-9): 132-133, t. 2, f. 35-38. 1862. Tinus ramiflorus (Oerst.) Kuntze, Revis. Gen. Pl. 2: 975. 1891. Stylogyne ramiflora (Oerst.) Mez, Pflanzenr. (Engler) IV, 236(Heft 9): 272. 1902. TYPE: 
Nicaragua. Zelaya: Prope Tortuga, Apr. 1847 (fl.), A. Oersted 31 (lectotype, designated by Lundell [1966: 199], C, C image as F neg. 22970).

Ardisia guatemalensis Mez, Pflanzenr. (Engler) IV, 236(Heft 9): 92. 1902. TYPE: Nicaragua. Chontales: [non "Guatmala, Aioyapa," Mez, 1902: 92], Acoyapa, 15 Feb. 1841 (fr.), E. von Friedrichsthal 857 (holotype, W). Stylogyne reticulata Mez, Pflanzenr. (Engler) IV, 236(Heft 9): 269. 1902. TYPE: Colombia. Cauca: Popayan Mpio., near Popayán, s.d. (fl.), J. Goudot s.n. (holotype, P).

Stylogyne funckiana Mez, Pflanzenr. (Engler) IV, 236(Heft 9): 271. 1902. TYPE: Venezuela. Carácas in the Nahe von Guareras, 1000 m, Mar. 1843 (fl.), H. Funck \& L. Schlim 456 (lectotype, designated here, P; isotypes, BM, G, G-BOIS, P, W, W image as F neg. 21982).

Stylogyne nicaraguensis Lundell, Wrightia 3(6): 110. 1964. TYPE: Nicaragua. Zelaya: Breñales espesos de La Esperanza, Río Grande, 0-15 m, 10 abr. 1949 (fl.), A. Molina R. 2125 (holotype, F).

Stylogyne standleyi Lundell, Wrightia 3(6): 110. 1964. TYPE: Panama. Canal Area: Barro Colorado Island in Gatún Lake, ca. 120 m, 18-24 Nov. 1925 (fl.), P. Standley 41048 (holotype, US; isotype, BM).

Mez (1902: 271) listed one collection (H. Funck \& $L$. Schlim 456) from two herbaria (G-BOIS and P) for his type of Stylogyne funckiana. Fortunately, all these sheets are present and they are of more or less equal quality. It should be noted that two sheets of $H$. Funck \& L. Schlim 456 are present at $\mathrm{P}$; one is annotated by Mez, while the other is not and is eliminated as a lectotype candidate. It should also be noted that a sheet of this type is present in the general collection at $\mathrm{G}$, but likewise was not annotated by Mez and is eliminated as a lectotype candidate. We designate the G-BOIS collection as the lectotype for this taxon, because it was annotated by Mez in 1901 and is of slightly better quality, primarily because it possesses an apical shoot.

\section{4b. Stylogyne turbacensis subsp. turbacensis.}

Cissus pentandra Willd. ex Schult. \& Schult. f., Mant. 3 (Schultes \& Schultes f.) 3: 248. 1827. TYPE: Colombia. s. loc., 1799-1804 (fl.), A. von Humboldt \& A. Bonpland 1446 (holotype, B-W 3005).

Stylogyne balaensis Mez, Pflanzenr. (Engler) IV, 236(Heft 9): 271. 1902. TYPE: Ecuador. Guayas: Balao Cantón, bei Balao in Wäldern, Dec. (fl.), H. Eggers 14304 (lectotype, designated here, M; isotype, US).

Icacorea granatensis Rusby, Descr. S. Amer. Pl. 79-80. 1920. Replacement synonym: Ardisia rusbyana Standl., Publ. Field Mus. Nat. Hist., Bot. Ser. 4(8): 250. 1929. Icacorea rusbyana (Standl.) Lundell, Phytologia 49(4): 351. 1981. TYPE: Colombia. Magdalena: Santa Marta Mpio., Santa Marta, near Bouda, ca. $1500 \mathrm{ft}$. [457 m], Aug., 1898-1899 (fl.), H. Smith 432 (holotype, NY; isotypes, GH [2], K [2], MICH, MO, UC [2], US).

Stylogyne guatemalensis S. F. Blake, Contr. U.S. Natl. Herb. 24(1): 16. 1922. TYPE: Guatemala. Izabal: Quebradas, 19-22 May 1919 (fl.), H. Pittier 8624 (holotype, US; isotype, NY).

Stylogyne perpunctata Lundell, Bull. Torrey Bot. Club 69(5): 398. 1942. TYPE: Belize. Stann Creek: Silk Grass
Creek Reserve, 10 Sep. 1939 (fr.), P. Gentle 2990 (holotype, MICH; isotypes, A, K, LL, NY).

Stylogyne turumiquirensis Steyerm., Fieldiana, Bot. 28(3): 479, fig. 109. 1953. TYPE: Venezuela. Sucre: Cerro Turumiquire, N-facing slopes above La Trinidad, SW of Cocollar, 2100-2200 m, 5 May 1945 (fl.), J. Steyermark 62539 (holotype, F; isotype, NY).

Ardisia ibaguensis Lundell, Wrightia 3(8): 197. 1966. Icacorea ibaguensis (Lundell) Lundell, Phytologia 49(4): 349. 1981. TYPE: Colombia. Tolima: Ibagué, 700-800 m, 2 Mar. 1952 (fl., fr.), M. Koie 5138 (holotype, C; isotype, LL [fragm.]).

Ardisia platyphylla Lundell, Wrightia 4(2): 62. 1968. Icacorea platyphylla (Lundell) Lundell, Phytologia 49(4): 350. 1981. TYPE: Venezuela. Monagas: Cerro Guácharo, above Guácharo Cave, near Guácharo, near summit, 1500-1620 m, 23 Apr. 1945 (fr.), J. Steyermark 62324 (holotype, F, F images as F neg. 68327, LL neg. 1971-84; isotypes, NY, US, US image as LL neg. 1971-84, VEN, VEN image as LL neg. 1971-84).

Stylogyne oaxacana Lundell, Wrightia 4(2): 72. 1968. TYPE: Mexico. Oaxaca: Tuxtepec Distr., Chiltepec \& vic., 22 m, 13 July 1940 (fl.), G. Martínez C. 19 (holotype, $\mathrm{LL}$; isotypes, A, MEXU, UC, US).

Mez (1902: 271) listed only one collection, $H$. Eggers 14304, from two herbaria (L, M) for his type of Stylogyne balaensis. A search of the L herbarium failed to reveal a specimen and it is presumed to be lost. Since the M sheet is present, it is designated as the lectotype. Some confusion has been caused by the fact that a sheet of a different collection, Eggers 15071, was labeled as "Stylogyne balaensis n. sp." in B but was destroyed in 1943 (Hiepko, 1987). This was photographed by Macbride (B image as F neg. 4837) and erroneously labeled as a type. Although widely distributed, this collection was clearly not mentioned in Mez's protologue.

35. Stylogyne viridis (Lundell) Ricketson \& Pipoly, Sida 18(4): 1171, fig. 2. 1999. Basionym: Parathesis viridis Lundell, Phytologia 56(1): 26. 1984. TYPE: Venezuela. Amazonas: $0-1 \mathrm{~km} \mathrm{~S}$ of San Carlos de Río Negro, $01^{\circ} 51^{\prime} \mathrm{N}, 067^{\circ} 03^{\prime} \mathrm{W}$, 120 m, 4 Feb. 1980 (fr.), R. Liesner 9046 (holotype, MO; isotype, VEN not seen).

Acknowledgments. We thank the Missouri Botanical Garden for their support of this project. We gratefully acknowledge the loans from many herbaria that made the study possible, along with our collaborators who supplied us with much critical material. We owe a great deal of thanks to the following researchers for searching their respective herbaria and scanning specimens. Without their efforts, this work would never have been possible: Christian Bräuchler (M), Gerard Thijsse (L), Peter "Pete" Phillipson (MO, P), and Laurent Gautier (G). We also thank Yvette "Tivvy" Harvey (K) for her 
continual support of our research and her willingness to constantly dive back into the "dusty cabinets" and locate our odd requests; Jochen Heinrichs (GOET) for providing the information regarding the GOET and Grisebach collections; Mia Ehn (S) for providing information in regard to the Swartz Herbarium; and the library staff of the Missouri Botanical Garden, especially Doug Holland, Victoria McMichael, and Mary Stiffler, for their remarkable knowledge of botanical literature that made this work possible. We acknowledge the use of the Biodiversity Heritage Library for making many of the useful texts cited in this paper available online. Finally, we thank Jon Ricketson's faithful volunteer Mary Bard (MO) for her tireless help and Miriam Agudelo-Pipoly, wife of John Pipoly, for her infinite patience waiting for Pipoly to finish working on this paper late nights and weekends.

\section{Literature Cited}

Agostini, G. 1970. Notes on Myrsinaceae. I: Generic assignment of Conomorpha sodiroana Mez, Ardisia ambigua Mart., and related species. Phytologia 20(7): 401-403.

Candolle, A. L. P. P. de. 1841. Second mémoire sur la famille des Myrsinéacées. Ann. Sci. Nat., Bot., Sér. 2, 16: 65-97.

Carrijo, T. T., M. F. Freitas \& A. L. Peixoto. 2009. The identity and typification of Stylogyne laxiflora (Myrsinaceae). Nordic J. Bot. 27: 454-455.

Farr, E. R., J. A. Leussink \& F. A. Stafleu. 1979. Stylogyne. P. 1700 in Nominum Genericorum (Plantarum), Vol. III. Bohn, Scheltema \& Holkema, Utrecht.

Grisebach, A. H. R. 1861. Myrsineae. Pp. 392-397 in Flora of the British West Indian Islands. L. Reeve \& Co., London.

Hiepko, P. 1987. The collections of the Botanical Museum Berlin-Dahlem (B) and their history. Englera 7: 219-252.

Howard, R. A. 1989. Myrsinaceae. Pp. 39-53, fig. 17-24 in Flora of the Lesser Antilles: Leeward and Windward Islands. Arnold Arboretum, Harvard University, Jamaica Plain, Massachusetts.

— \& E. S. Howard. 1982. The West Indian Taxa in Solander's "Florula Indiae Occidentalis. J. Arnold Arbor. 63(1): 63-81.

Imkhanitskaya, N. N. 1996a. Type specimens of Myrsinaceae in the Herbarium of Komarov Botanical Institute (St. Petersburg, LE). 5. Neotropical taxa of the genera Geissanthus-Weigeltia. Bot. Žhurn. (Moscow \& Leningrad) 81(10): 22-31.

1996b. Type specimens of Myrsinaceae in the Herbarium of Komarov Botanical Institute (St. Petersburg, LE). 1. Palaeotropical taxa of the genus Ardisia. Bot. Žhurn. (Moscow \& Leningrad) 81(9): 31-42.
Loddiges, C., G. Loddiges \& W. Loddiges. 1825. The Botanical Cabinet, Vol. 11(4), tab. 1083. John and Arthur Arch., John Hatchard, C. Loddiges \& Sons, G. Cooke, London.

Lundell, C. L. 1966. Studies of the American MyrsinaceaeIII. Wrightia 3(8): 192-199.

. 1971. Family 150. Myrsinaceae in R. E. Woodson \& R. W. Schery (editors). Flora of Panama. Ann. Missouri Bot. Gard. 58: 285-353.

1974. Studies of American Plants-VII. Wrightia 5(3): 51-72.

Martius, C. F. P. von. 1841. Inest: de Martius, Herbarium Florae brasiliensis. Continuatio. Flora 24(Beibl. 2): 1-112.

_ \& F. A. W. Miquel. 1856. Myrsineae. Pp. 269-324, fig. 28-59 in C. F. P. von Martius (editor), Flora Brasiliensis, Vol. 10. Munich, Vienna, Leipzig.

McNeill, J., F. R. Barrie, H. M. Burdet, V. Demoulin, D. L. Hawksworth, K. Marhold, D. H. Nicolson, J. Prado, P. C. Silva, J. E. Skog, J. H. Wiersema \& N. J. Turland (editors). 2006. International Code of Botanical Nomenclature (Vienna Code). Regnum Veg. 146.

Mez, C. C. 1901. Myrsinaceae. Pp. 389-433 in I. Urban (editor), Symbolae Antillanae, Vol. 2(3). Fratres Borntraeger, Berlin.

- 1902. Stylogyne. Pp. 263-279 in H. G. A. Engler (editor), Das Pflanzenreich, IV 236(Heft 9). Wilhelm Engelmann, Berlin.

- 1920. Additamenta monographica 1919. III. Repert. Spec. Nov. Regni Veg. 16(468-473): 410-425.

Nicolson, D. H. \& C. E. Jarvis. 1990. Solander's manuscript Florula Indiae Occidentalis and Swartz's Prodromus. Taxon 39(4): 615-623.

Pipoly III, J. J. 1989. Notas sobre el género Stylogyne A. DC. (Myrsinaceae). Ernstia 53: 1-9.

- 1991. Stylogyne rodriguesiana (Myrsinaceae): A new androdioecious species from Amazonia. Novon 1(4): 202-203.

— \& J. M. Ricketson. 2005. New species and nomenclatural notes in Mesoamerican Ardisia (Myrsinaceae). Novon 15(1): 190-201.

Ricketson, J. M. \& J. J. Pipoly III. 1997. Nomenclatural notes and a synopsis of Mesoamerica Stylogyne (Myrsinaceae). Sida 17(3): 591-597.

— \& 2003. A new species of Stylogyne (Myrsinaceae) from Darién, Panama. Sida 20(3): 919-922. ¿ — 2009. Myrsinaceae. Pp. 468-568 in G. Davidse, M. Sousa S., S. Knapp \& F. Chiang C. (editors), Flora Mesoamericana, Vol. 4(1): Cucurbitaceae a Polemoniaceae. Universidad Nacional Autónoma de México, México, D.F.

Stafleu, F. A. \& R. S. Cowan. 1981. Taxonomic Literature, Vol. III: Lh-O. 2nd ed. Regnum Veg., Vol. 105.

Stearn, W. T. 1980. Contributions to West Indian Botany. Taxon 29(1): 1-13.

Swartz, O. 1788. Nova Genera \& Species Plantarum seu Prodromus..., Vol. 1: [1]-158. Stockholm. 


\section{$2 \mathrm{BHL}$ Biodiversity Heritage Library}

Ricketson, Jon M and Pipoly, John J. 2010. "A Synopsis of Neotropical Stylogyne (Myrsinaceae)." Novon a journal of botanical nomenclature from the Missouri Botanical Garden 20, 437-447.

View This Item Online: https://www.biodiversitylibrary.org/item/123332

Permalink: https://www.biodiversitylibrary.org/partpdf/122056

\section{Holding Institution}

Missouri Botanical Garden, Peter H. Raven Library

\section{Sponsored by}

Missouri Botanical Garden

\section{Copyright \& Reuse}

Copyright Status: Permission to digitize granted by rights holder Rights: https://www.biodiversitylibrary.org/permissions

This document was created from content at the Biodiversity Heritage Library, the world's largest open access digital library for biodiversity literature and archives. Visit BHL at https://www.biodiversitylibrary.org. 